\title{
ANALYSIS OF THE CASE STUDIES VIDEO RECORDINGS
}

\author{
Petr MACH - Regina JANÍKOVÁ
}

\begin{abstract}
Case study method of didactic situations is a modern procedure of effective development of professional abilities in future teachers. I have been using the method for many years in future teachers training in the field of preparation of subject methodologies. A case study does not develop only the subject and didactic competences of future teachers. The self-evaluation and self-reflection processes in students also play an important role. For this purpose the third-analytical - phase of the study is carried out. Two basic methods are used for a complex analysis - macro-analytic and micro- analytic. The macro-analytic method is used to examine the course and the results of the case study: suitability of the used methods, forms and tools; using communicative tools, creating proper climate etc. The micro-analytic method is used to find out changes in students personalities and causes of the outer demonstrations of the case study. One of the examined phenomena is e.g. flexibility and creativity in adjusting the pre-concept to the course of the realization phase of the study. The initial research of this area of case studies was carried out within the project no. 406/07/0109 (Nonverbal creativity in technical education).
\end{abstract}

Key words: case study method, didactic situation, professional abilities, didactic competences macroanalytic method, micro-analytic method, creativity.

\section{ANALÝZA VIDEOZÁZNAMŮ PŘÍPADOVÝCH STUDIÍ}

\begin{abstract}
Abstrakt: Metoda př́padových studií didaktických situací je moderní postup, jak lze velmi efektivně rozvíjet profesni schopnosti budoucich učitelì. Již řadu let tuto metodu využivám při prípravě budoucích učitelů v rámci výuky oborových didaktik. Př́ipadová studie nerozvíji jen odborné a didaktické kompetence budoucích učitelů. Její neméně dưležitou úlohou je rozvoj autoevaluačních a sebereflexních procesů studentů. K tomu slouži třetí - analytická - fáze studie. Ke komplexní analýze se použivají dvě základní metody - makroanalytická a mikroanalytická. Makroanalytickou metodou se vyšetřuje prüběh a výsledky př́padové studie: vhodnost použitých metod, forem a prostředkü; použivání komunikačnich nástrojů; vytváření vhodného klimatu atd. Mikroanalytickou metodou se zjištují změny v osobnosti studentů a kazuistika vnějšich jevi̊ př́padové studie. Jedním ze zjištovaných jevi je napríklad flexibilita a kreativita při přizpůsobeni prekonceptu prüběhu realizačni fáze studie. Počáteční výzkum této problematiky př́padových studii byl uskutečněn v rámci řešení projektu č. 406/07/0109 (Nonverbálni tvořivost v technické výchově).
\end{abstract}

Klíčová slova: metoda prípadových studií, didaktická situace, profesní schopnosti, didaktické kompetence, makroanalytická metoda, mikroanalytická metoda, kreativita.

\section{Introduction}

Present educational system imposes high requirements on teachers of all levels. It requires among others innovations in the area of preservice professional development for teachers of all types. It influences also the life long education of practicing teachers. It is necessary to solve global problems of teacher education, e.g. the suitability of two-stage structured model of teacher training programs. Furthermore, the issue of cognitive aspect of teacher training must be dealt with - the scope and depth of the knowledge basis of particular subjects and their combination. The function of information and communicative technologies is not solved sufficiently, namely didactic technologies in both teacher training and the educational process itself. Personality development is marginalized in teacher training, mainly the development of creative abilities and skills to solve conceptual matters and dynamic changes in the educational process. One of the ways of improvement the personality and professional development is to include the case study method. The case study is basically a complex and creative solution of a given didactic situation in simulated didactic environment. It is based on interactive and situational learning and deciding. The didactic 
situation is understood as a short term interaction between the teacher and pupils (or just between pupils). It is characterized by a given content and way of solution. It means by chosen methods, means and forms, communicative tools, created atmosphere etc. It brings good results in creating basic teaching skills. It helps to diminish the fear of failure at the beginning of teaching practice.

\section{Theoretical outcomes}

Case study as a teaching method has its roots in the USA around the middle of the last century. It was used at Law faculties for reconstruction of completed trials. Later it became popular for training of managers, businessmen, politicians, physicians etc.

Case study exists in the form of descriptive or research (problem) document. The content is formed by a thorough multi-dimensional analysis of connections, elements and reality of the situation. The focus is on explicit discussion with the sense of detail and various suggestions of the solution. [1]

Basic principles of a proper case study were evolved that are usable in other fields, e.g. upbringing and education:

a) Involvement of participants - involving the people who have an interest in work.

b) Support - identifying and overcoming any barriers to involvement.

c) Planning - gathering evidence and resources, making schedules, . .

d) Suitable Methods - agreeing and using methods that are fit for purpose.

e) Sharing Information - ensuring that necessary information is shared between the participants.

f) Working Together - using clear procedures to work with one another effectively and efficiently.

g) Working with Others - working effectively with others to develop knowledge, skills and selfconfidence of participants.

h) Feedback - processing the results and cooperation of participants.

i) Monitoring \& Evaluation - checking and assessing the outcomes to meet the standards. [2]

The case study concept that I use for subject methodologies has a wider and more complex notion. It can be understood as a broader participation method. Positive cooperation of all participants is vital. From the psychology of learning point of view a case study is a concrete tool of interactive and situational learning. Students are taught to solve complex interactions mainly in the realization phase of the study. Interactive learning is applied in the analytical phase, in reflection from the peers. From the point of view of situational learning it is necessary for the case studies to meet the following requirements:

- The study topic should draw on didactic reality (real subject, school)

- Should aim at a specific goal, but in multiple ways, and with creativity

- The course and the results should have a divergent character, search for multiple solution

- The Study should develop an entire, synthetic and contextual approach to the given topic. To process the topic from the viewpoint of subject, didactics, pedagogy, psychology, economy, ethics etc.

- In should develop in students professional individuality, teacher personality

- The study should be held in a positive, open and constructively creative environment.

From the given requirements the basic structure of case studies results that is applied in subject methodologies. Every study must comprise: 1. Social communicative component. Participants learn to design a common activity, accept various options of behavior, seek and from contacts in the family, control cooperation, show praising feelings, analyze barriers and failures of cooperation, play different social roles, influence social-cultural values, revise mutual behavior in the group, regulate the social climate, use a wide range of communication tools and other factors.

2. Meta-cognitive component. It is a psychodidactic application of meta-cognitive training. The training focuses on the area of changes in personality and cognitive preconditions of the participant - the so called inner area. Then the training focuses on the outer area - contextuality of didactic situations, influencing the conditions, choice of concepts, methods, forms, means etc. Application of this component results from revised Bloom taxonomy. During the case study it is important to observe basic principles of meta-cognitive training:

- The principle of processuality (greater orientation on the process itself than the result).

- The principle of reflectivity (priority of one's knowledge development, learning, thinking, 
self-instructing, self-forming, self-evaluation, using processes of interior oriented analysis, reactions to inner and outer reflections..).

- The principle of generation (to develop the ability to elaborate, classify, categorize, transform ... ). The principle of affection (empathy and motivation readiness).

- The principle of regulation (adjust the processes to given aims and conditions) and to reflection.

3. Profession component. It is the development of main teacher competencies, ability to create conceptual documents, choose learning strategies. In this component the link to framework and school educational programs is important.

Case studies in this form are based on the solution of specific didactic situations. A didactic situation means a short term, finished interaction between the teacher and a pupil or pupils, or between pupils. It occurs in an identified environment that considerably influences the interaction.

The content is of cognitive character, affection character or sensomotoric (psychomotoric) character. The content can be chosen by the student or it is assigned by the teacher. The student independently modifies the environment, chooses the methods, forms and means needed for the solution of the situation and so of the whole case study.

The case study is run by an educator (teacher at the faculty) and its course has three basic phases:

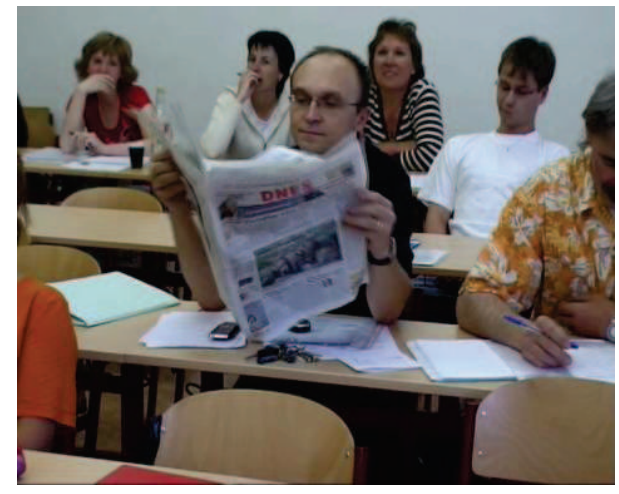

Fig. 1 Non-standard element a

These non-standard elements of didactic situation must be solved by the" teacher" using situational decision. a) The choice and preparation of didactic situation. Creation of pre-concept anticipated course of the didactic situation and so the whole case study. The student defines in writing the conditions, learning environment, methods, tools of communication. He estimates the behavior and reactions of his pupils as well as his own, tries to reach the needed climate. In this way he develops the main subject, pedagogical and psychological competencies of teacher profession.

b) The second phase is based on pedagogy of the experience. The didactic situation is realized in simulated environment (does not occur in the real classroom, school). Peer students play the role of the pupils of the school. They must identify with their mentality, psycho, behavior and knowledge. The learning process is video-recorded. It is thus a kind of microteaching or videosimulation. The camera does not create a passive record. It is important to catch all important moments of the student's activity in the role of the teacher as well as the pupils' activities. To grasp the details of positive and negative activities and behavior of all participants. The time of the realization period should not exceed about ten minutes. The purpose is to show a didactic situation, not a part of a lesson. Disturbing elements can be inserted into the study (realized by the educator). These range from problem elements to conflict elements ( arrogance, aggressiveness of the pupil).

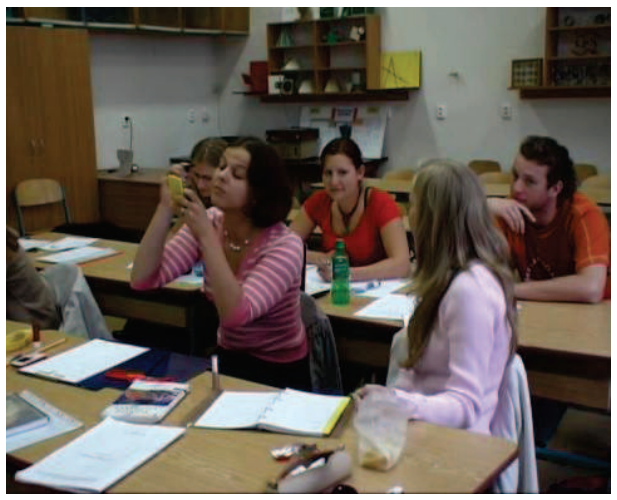

Fig. 2 Non-standard element $b$

c) Phase of reflection and self-reflection. In this phase meta-cognitive elements apply best. The student tries to see all the important moments of his role as a teacher 
(in both positive and negative sense). Reflection follows and evaluation of other participants in the study - peers in the role of pupils. The results are compared analytically and confronted with the video-recording. This phase is very demanding for both the students and the educator. Its results influence the success of the whole case study.

d) The last phase is again an individual matter of the student. Based on the results of the previous phase the students adjust the original concept of the study. He adds results of reflection and analysis. In case of serious shortcomings in the presented situation the student has to redo the original pre-concept. In this way he creates the postconcept of the case study.

e) Case studies that have been carried out in the last three years have one more phase. It is called the deferred reflection. This phase will be dealt with later in the paper.

\section{Complex analysis}

At present there are about one hundred of video recorded case studies that have been made since 2004. It represents a sufficient database for complex analysis. The case studies made before 2004 are not included in the examined sample. Those were built up on different starting requirements and different situation in our educational system (before the curricular reform). Ninety video recordings were analyzed and questionnaires and personal reflections of 95 probationers were processed. Basic methods of the research were the followings - observation, transcription, analysis of video-recording, questionnaire method (mainly with scaled items), controlled interview and spontaneous account.

First I will focus on the third analytical reflective phase of the study. It is a microanalytical activity when the system activity of the "educator " (defined in the pre-concept) is compared with the dynamic situational activity. This is a symptom of the quickly changing interaction and communication between "the teacher" and the pupils (between learners) in the model environment. As early as the realization phase, socio psychological states occur when there is oscillation between the system and situational solution in relation to the subject matter, didactic and outer contexts. . The aim of this self-reflection is (it can be also called autodiagnosing) is for the teacher to manage to process all the feedback information about his activity and learners activities from the course of the case study. Here processing means analysis, evaluation, identification or rejection, search for other solution and the following generalization. By the term feedback information we understand one's own reflection, views, attitudes, and evaluation of the peers. Self-reflection is very valuable when gained through the project method, when "the teacher" carries on conversation with his image in the videorecording of the situation. For students it is usually very difficult to confront their often selfconfident ideal ego with the faulty ego in the recording. When analyzing personal responses I often come across utterances such as "Did I say this?, "I never behave like that.", I would never do that". In most cases these conclusions refer to the analysis of used communicative tools (verbal and non-verbal). The most frequent drawbacks are the followings: overusing parasite expressions, anacoluts, unfinished statements, wrong word order (putting interrogative pronouns at the end of the sentence), inapt gestures, etc. There are also content errors, wrong interpretation of notions, factual mistakes, grammar and spelling mistakes in writing.

It is evident from the statistics that $89 \%$ of respondents in the course of the realization phase do not check and correct their language, $60 \%$ of respondents are not able to control their activity - behavior, moving around the classroom, gestures, miming, clothes, are not able to react to the failure of teaching aids ( laboratory equipment, presentation technologies) etc. They focus mainly on the subject matter of interaction.

The analysis of conflict elements solving implanted in the course of situation brought some interesting result. Almost $5 \%$ of respondents did not realize the existence of conflict elements. 20 $\%$ of respondents notice the conflict situation, but did not try to solve it. They used the sublimation method risking the escalation of the conflict. Only $12 \%$ of respondents managed to aptly assess the causes of the developing conflict, articulate the attitudes and opinions of all parties and suggest and put through a procedure leading to the solution of the conflict. Others used the given rules and atmosphere in the environment and were able to get support from other participants of the study.

To describe here all the pedagogical and psychological phenomena of microanalysis is beyond the scope of this paper.

Le us focus on some of the conclusions of the macro-analysis of case studies. The most 
important methods in this part are observation and transcription of the video-recording of the study. Transcription is the most demanding activity from the viewpoint of time and concentration demands. Using SW Pinnacle Studio Digital the recording is transformed to MPEG 2 format for the transcription. Unfortunately I do not have any other SW (e.g. Videograph), that can carry out the transcription according to given parameters. The transcript of the content must be carried out manually. For the transcription the simplified Pauli, Reusser system is used. [3]

Only the three most important categories that were observed are given here:

- Contribution of doing case study for professional competences development

- Choice of lesson phase (into which the didactic situation is incorporated)

- Choice of predominant form of teaching

- Choice of predominant method of teaching

- Using technical teaching aids (presenting and interactive technologies)

- Using other aids, equipment and other teaching tools

- Work with time dimension

- Work with the aim

- Subject matter level

- Language level

- Motivation

- Work with Error and some other less important ones.

Evaluation of some categories.

First category - contribution of the case study to the professional development of the students was evaluated with a scaled questionnaire twice during the teaching period. For the first time at the beginning of the semester, when student started preparing the pre-concepts of didactical situation. $72 \%$ of respondents stated high contribution of the case study to their professional development. $5 \%$ of them expressed essential disagreement with the contribution and $9 \%$ did not have any opinion (they could not assess the observed phenomenon). When comparing results according to gender - female students had more positive attitude (89\%).

Second evaluation of the same questionnaire took place after finishing the teaching period, when all students did case studies.

Another category was the choice of the phase of a lesson - where the students put deliberately the didactic situation. It was evident from the transcription that $87 \%$ of respondents chose the exposition phase it is when creating new knowledge and skills. It from further analysis it is possible to derive that most respondents perceive teachers as providers of new knowledge. Even the results of the following category - methods used - agree with these conclusions.

The most frequent method is presentation. The frequency of choice in this method is $72 \%$. From the following analysis is it evident that students only exceptionally accomplished this method with other supplementary methods visualization or demonstration. Only in 5\% the presentation method was extended by controlled discovery and certain problem elements. The lowest measurable frequency was shown in the problem method group. In this group brainstorming prevails (60\% out of all problem methods). Summary results are in Fig. 3.

From the wide scale of methods students limited their choice to the followings: presentation, problem presentation, explanation, dramatization, and didactic games, problem methods. Verbal methods prevail suitable for trans-missive teaching style.

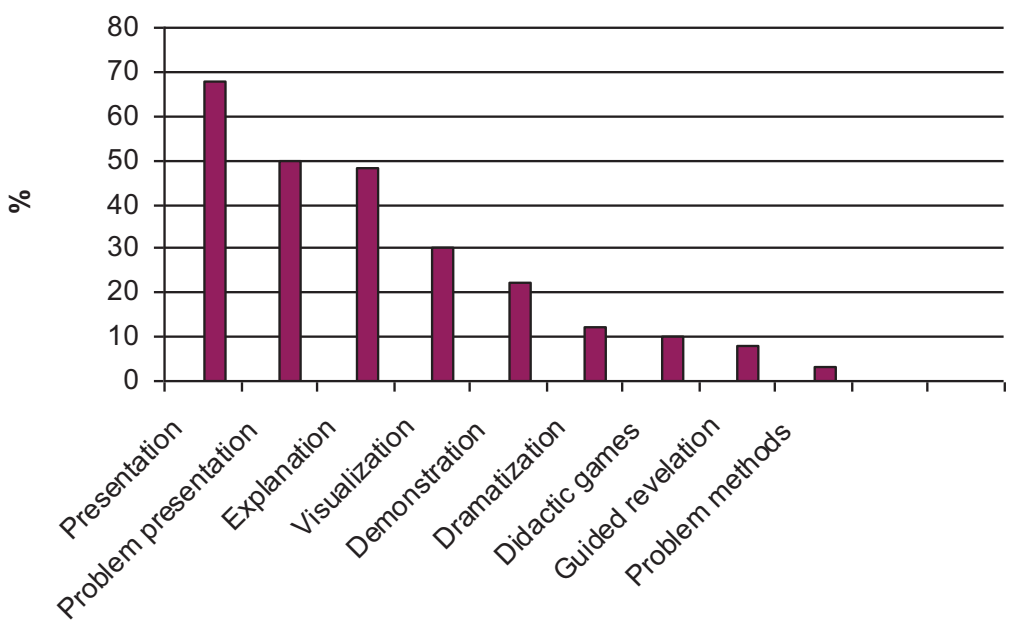

Fig. 3 Frequency of used methods 
This fact is supported by student J.S. statements. "Until the end of the study I believed that the teacher who ca speak well can teach well too. The experiencing case studies at the faculty (mine and those of other students) and some days of teaching practice I think, that it should be rather the learners who should speak and work".

(record sheet no. 56) It is necessary to admit that didactic situations do not provide enough space for a wide choice of methods in when compared to teaching whole didactic units.

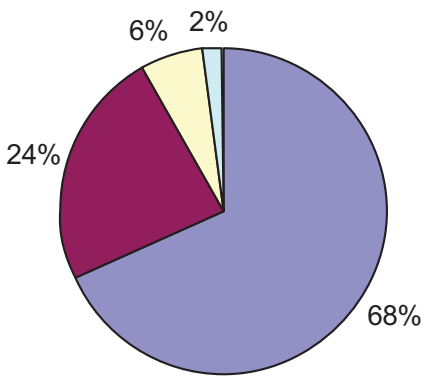

Fig. 4 Frequency of used forms

Using technical didactic means will be presented here. Latest presentation technology, such as PC, Data projector, audio equipment, interactive boards from various providers were available for the students. Only $23 \%$ of respondents used there technologies, mainly PowerPoint presentation. Only one student prepared a short program for interactive board. These conclusions correspond with the table of used methods (prevailing verbal methods). When observing the correlation between using didactic technologies and gender it was not proved that girls felt more negative about these technologies.

Time dimension parameter results were also interesting. Only $5 \%$ of respondents were able to estimate time properly (with regard to aims and content of the didactic situation) in the preconcept study. They managed to keep this time also during the realization phase of the study. The others needed more time. $12 \%$ of students exceeded the given time by twice as much. These conclusions correspond with the results of the micro-analysis. $60 \%$ of students are not able to diagnose and revise their activities during the study. They do not perceive the remaining time for the planned activities.

I would like to mention here evaluation of the last phase of the case study - the phase of
Choice of didactic forms. In this category there is bigger variety. Frontal forms of teaching were most frequent (68\%). Others such as group work (37\%), cooperative learning, pair work were also often used. $39 \%$ of students could radically change the arrangement of conditions reordering desks, move to a more suitable classroom etc. Only $3 \%$ of students did not change the arrangement despite the unsuitability to the aims of the study. $\square$ Frontal forms
$\square$ Group work
$\square$ Cooperative learning
$\square$ Pair work

deferred reflection. This phase takes place more than six months after completing the case studies. .. Students then have their final teaching practice. After completing it I meet them once again to analyze the contribution of case studies to their professional development and development of didactic competences now with the reflection of their real pedagogic activity. I go back to the category of contribution of case studies to their practice. At the beginning of their teaching practice, $72 \%$ of students claimed case studies are very likely to contribute to their professional development. From the analysis of responses it is evident that almost $100 \%$ of them changed their statement and claimed that completing case studies ( their own or participating in those of other students ) considerably helped them manage the role of the teacher and cope with various problems of teaching Only one students stated that case study did not help her. I will provide an extract from the record of response of student A. N. "My first independent lesson look place in the last year class in subject of Accounting My mentor only told me the lesson topic - revising for school -leaving exam and defined the terms they are supposed to revise. I went through all final questions to know what issues I will continue with. I prepared the theory and many pattern examples from the real 
company practice. My advantage was that I knew the issues from the faculty. So well prepared I started teaching. From the first minutes I noticed disturbance, neglecting, and pupils' disagreement with my style of teaching. Pupils attacked my person, age, clothes, inexperience and were unwilling to work in my way. They are not going to work like this. Now I recollected a case study when my colleagues did something similar to me. I remembered how embarrassed I was and did not defend my approach. Now in the real situation, I was able to get the situation under control, persuade the pupils to accept my way of teaching and almost one half of the class started to cooperate. After the lesson I consulted the situation with my mentor. She said that pupils are used to dictation of sentences they are supposed to memorize for the final school leaving exam. I started doubting whether our schools really want to change the ways of teaching. But owing to the case study, I completed the teaching practice without any painful mental consequences". (record sheet no. 15)

\section{Conclusion}

The number of respondents of my research does not allow to provide any generalizing conclusions. Also the methodology of verifying the validity of questionnaires was not perfect. Nevertheless the results provide some information. Case studies definitely contribute to creating key pedagogical habitudes in students. Students often fail to use modern methods and approaches in teaching. They know these theories only theoretically. Being exposed to the specific pedagogical reality they easily adopt traditional pragmatism and classical style of teaching.

When searching for similar attempts of modern approach to teaching subject methodologies, I appreciate a very inspiring research in the field of Teaching Technical Subjects at Technical University in Ostrava. Teaching and research is more focused on development of creativity in teacher trainees using microteaching and case studies. Results and conclusions obtained by M. Miklošíková [4] within the "CR program" (program for support and development of creativity in students of Teaching Technical Subjects program) are in many respects similar. It is necessary to make a lot of effort to transform the habits gained in case studies into practically applicable pedagogical skills.

\section{Literature}

[1] MERSETH, K. K. The early history of casebased instruction: Insights for teacher education today. Journal of Teacher Education, 1991, 42(4), 243-249. EJ 438532.

[2] HERRIED, C. F. What Makes a Good Case? [online].

Dostupné

na

http://ublib.buffalo.edu/libraries/projects/cases/te aching/good-case.html.

[3] PAULI, CH., REUSSER, K. Transkriptionsmanual für das Videoprojekt Mathematiklernen und und Mathematikleistungen in unterschiedlichen Unterrchtskulturen. Zürich: Universität Zürich, 2002.

[4] Miklošíková, M. Kreativita a učitelství odborných predmètů. Ostrava: Technická univerzita Ostrava, 2009. ISBN 978-80-2481952-5.

PaedDr. Petr Mach, CSc.

University of West Bohemia in Pilsen, Faculty of Education, Department of Technical Education, Czech Republic

E-mail: pmach@kat.zcu.cz

Mgr. Regina Janíková

University of West Bohemia in Pilsen, Faculty of Arts, Department of Archaeology, Czech Republic

E-mail: reginajanikova@centrum.cz 